\title{
The Role of P53 Serine 46, Burkitt Cell Lymphoma 2 (BCL-2), and Cysteinyl Aspartate Specific Proteinase 3 (Caspase 3) Proteins as Risk Factors in Abortion
}

\author{
Herlambang Herlambang ${ }^{1}$, Firman F. Wirakusumah ${ }^{2}$, Jusuf S. Effendi ${ }^{2}$, \\ Ida Parwati ${ }^{3}$, Leri Septiani ${ }^{4}$, Ahmad Faried ${ }^{5}$, Hiroyuki Kuwano ${ }^{6}$ \\ ${ }^{1}$ Senior Lecturer, Department of Obstetrics and Gynecology, Faculty of Medicine and Health Science, Universitas \\ Jambi/Raden Mattaher Hospital, Jambi, Indonesia, ${ }^{2}$ Professor, Division of Fetomaternal, Obstetric and \\ Gynecology Department, Universitas Padjadjaran/Hasan Sadikin Hospital, Bandung, Indonesia, ${ }^{3}$ Professor, \\ Pathology Clinics Department, Universitas Padjadjaran/Hasan Sadikin Hospital, Bandung, Indonesia, \\ ${ }^{4}$ Researcher, Obstetric and Gynecology Department, Universitas Padjadjaran/Hasan Sadikin Hospital, Bandung, \\ Indonesia, ${ }^{5}$ Associate Professor, Neurosurgery Department, Universitas Padjadjaran/Hasan Sadikin Hospital,

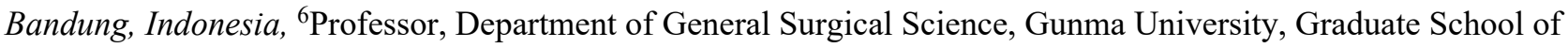 \\ Medicine, Japan
}

\begin{abstract}
An Incomplete abortion is one of the complications that often occur during pregnancy, but the biomolecular mechanism is still unknown. It has proven to be an increase in apoptosis activity that is controlled by a variety of proteins, including p 53 Ser $46, \mathrm{Bcl}-2$, and caspase 3 , in uteroplasenta and reproductive organs. The aim of the study is to measure the level of protein p54 Ser 46, Bcl-2, and caspase 3 in abortion and normal pregnancy. A case control study conducted in 38 cases of incomplete abortion and 38 normal pregnancies as a control. The level of protein of Ser 46, Bcl-2, and caspase 3 examined by ELISA independent/Duplo. The higher level of $\mathrm{p} 53 \mathrm{Ser} 46(>0,09 \mathrm{U} / \mathrm{mL})$ led to higher risks of abortion with OR 8.52; 95\% CI, 2.65 to 28.6. The higher level of Bcl-2 led to higher risks of abortion with OR 3.75; 95\% CI, 1.24 to 11.68 . The higher level of caspase $3(>7 \mathrm{mg} / \mathrm{mL})$ and p53 Ser $46(>0,09 \mathrm{U} / \mathrm{mL})$ led to higher risks of abortion with OR 71.15; $95 \%$ CI, 8.74 to 578.92 ; with the result of series $p, p, 0.001 ; p<0.008$; and $p=0.001$. Level of protein $p 53$ Ser 46 and caspase 3 in abortion is higher than normal pregnancies, while the Bcl-2 protein levels in abortion is lower than normal pregnancies.
\end{abstract}

Keywords: Burkitt cell lymphoma, cysteinyl aspartate specific proteinase 3, risk factors in abortion

\section{Introduction}

Abortion is the termination of pregnancy before 20 weeks pregnancy or fetal weighs less than 500 grams. It is still an obstetric problem that has not been uncovered $^{[1-3]}$. Abortion is one of the causes of maternal

\section{Corresponding Author:}

\section{Herlambang Herlambang}

Senior Lecturer, Department of Obstetrics and Gynecology, Faculty of Medicine and Health Science, Universitas Jambi/Raden Mattaher Hospital, Jambi, Indonesia e-mail: herlambang07@yahoo.co.id and fetal mortality today. The causes of abortion have been reported are due to genetic disorders such as abnormalities of the conceptus as a result of chromosomal abnormalities ${ }^{[4-6]}$. Other causes include developmental abnormalities of the zigot, embryo of placenta, infection, endocrines disorders and immunological disorders. Abortion is also influenced by maternal age, parity, and history of recurrent abortion ${ }^{[2,7-10]}$. Abortion is a highly complex process, controlled by variety of genes, including the gene $\mathrm{p} 53$, cl-2, and the caspase of cysteinyl aspartate specific proteinase (caspase). All of the genes play a role in the regulation of apoptosis either in a normal or abnormal circumstance which results in pregnancy failure. The involvement of apoptosis activator can cause excessive apoptosis. The presence of excessive 
apoptosis will continue with cell death characterized by caspase 3, ended with abortion ${ }^{[11-17]}$.

The excessive apoptosis in syncytiotrophoblast will result in failure of pregnancy, in addition to the role of the decidua and plasenta to give support and protect embryo development. Result of human studies has not found an association between the gene p53 through the protein $\mathrm{p} 53$ expression on Ser 46 and Bcl-2 agains caspase 3 in the first trimester and the association with the incidence of abortion. Based on that, we were interested to investigate ${ }^{[17-19]}$.

\section{Research Method}

The subjects were pregnant women with gestational age between 10-20 weeks who diagnosed with in incomplete abortion (as the case group), whereas normal pregnancy as a control group. The inclusion criteria are $10-20$ weeks of gestational age and maternal age between $16-35$ years. We excluded subjects with abnormal uterine; kidney disorders, heart disease, hypertension, diabetes mellitus, lung, thyroid, and other chronic diseases, malignancy; pregnant with help medication or taking hormonal drugs.

This is a comparative analytic study with case control design. The sample size was determined based on the formula to test the hypothesis by using a correlation coefficient $\mathrm{r}(n=\mathfrak{B}, 5 \approx \mathbf{3}$ people per group). The research activities carried out in the Section/ SMF Obstetrics and Gynecology FKUP/RSHS, Cibabat Cimahi Hospital, dr . Slamet Garut Hospital, and Gunma University, Japan. The independent variables are levels of protein p53 Ser 46, Bcl - 2 and caspase 3 ; the dependent variables are an incomplete abortion and normal pregnancy; by confounding variables that maternal age, gestational age, and parity.

We examined the levels of protein p53 Ser 46, Bcl2 and caspase 3 at the Laboratory of the Department of General Surgical Science, Graduate School of Medicine Gunma University, Maebashi, Gunma, Japan. The Shapiro-Wilk used for normality test data, the $\mathrm{T}$ test is used to compare two values average normal distribution of data, X2 test (Chi squared) was used to test for differences in percentage to the data presented in contingency tables, Mann-Whitney test was used to compare differences in 2 the middle value the data which are not normally distributed, Rank Spearman correlation test is used to find relationship between two numerical variables, Odd ratio: in the case-control study pointed to the ratio between the odds at-risk and non-risk groups, logistic regression aims to analyze data in multiple independent variables and nominal numeric scale, the nominal scale dichotomous dependent variable. Significance based on the value of meaningful when $\mathrm{p} \leq 0,05$, very meaningful $\mathrm{p} \leq 0,01$.

All of the subjects involved voluntary after receiving explanation of the advantages and disadvantages (informed consent), the subject were also free to resign at any time for any reason without causing changes in the quality of service.

\section{Result}

Characteristics of the study subjects according to maternal age, parity, and gestational age in normal pregnancy and abortion can be seen in Table 1. Range of ages between from 19 to 35 years, parity ranges from 1 to 4 , while for gestational age ranged from 10 to 14 weeks.

Table: 1. Characteristics of Subjects Research by Maternal Age, Total Parity and Gestational Age in Normal Pregnancy and Abortion

\begin{tabular}{|l|c|c|c|}
\hline \multirow{2}{*}{ Characteristics } & \multicolumn{2}{|c|}{ Gestation } & \multirow{2}{*}{ Significance } \\
\cline { 2 - 3 } & Abortus (n=38) & Normal (n=38) & \\
\hline Maternal age (year) & & & $\mathrm{Z}_{\mathrm{M}-\mathrm{W}}=1.282 \mathrm{p}=0.200$ \\
\hline$<20$ & $2(5.3 \%)$ & $1(2.6 \%)$ & \\
\hline $20-24$ & $4(10.5 \%)$ & $5(13.2 \%)$ & \\
\hline $25-29$ & $18(47.4 \%)$ & $13(34.2 \%)$ & \\
\hline $30-35$ & $14(36.8 \%)$ & $19(50.0 \%)$ & \\
\hline $\bar{X}(\mathrm{SD})$ & $27.6(4.2)$ & $28.8(4.6)$ & \\
\hline Median & 28 & 29.5 & \\
\hline Range & $19-35$ & $19-35$ & \\
\hline
\end{tabular}




\begin{tabular}{|c|c|c|c|}
\hline \multirow{2}{*}{ Characteristics } & \multicolumn{2}{|c|}{ Gestation } & \multirow{2}{*}{ Significance } \\
\hline & Abortus $(n=38)$ & Normal $(n=38)$ & \\
\hline Parity & & & $\mathrm{X}^{2}=0.234 \mathrm{p}=0.629$ \\
\hline $1-2$ & $26(68.4 \%)$ & $24(63.2 \%)$ & \\
\hline$\geq 3$ & $12(31.6 \%)$ & $14(36.8 \%)$ & \\
\hline Range & $19-35$ & $19-35$ & \\
\hline Gestational Age & & & $X^{2}=0.290 p=0.990$ \\
\hline 10 week & $9(23.7 \%)$ & $8(21.1 \%)$ & \\
\hline 11 week & $7(18.4 \%)$ & $6(15.8 \%)$ & \\
\hline 12 week & $10(26.3 \%)$ & $10(26.3 \%)$ & \\
\hline 13 week & $6(15.8 \%)$ & $7(18.4 \%)$ & \\
\hline 14 week & $6(15.8 \%)$ & $7(18.4 \%)$ & \\
\hline
\end{tabular}

Explanation: The $\mathrm{p}$ - value is calculated based on the Chi Square test or Mann-Whitney test

Meaningful when $p \leq 0.05$, very significant if $p \leq 0.01$;

$\mathrm{ZM}-\mathrm{W}=$ Mann-Whitney

Table: 2. Comparative Levels of Protein p53 Ser 46, Bcl-2 and Caspase 3 between Normal Pregnancy and Abortion

\begin{tabular}{|c|c|c|c|c|}
\hline \multirow{2}{*}{ Variable } & \multicolumn{2}{|c|}{ Gestation } & \multirow{2}{*}{$\mathbf{Z}_{\mathbf{M}-\mathbf{W}}$} & \multirow{2}{*}{ p-value } \\
\hline & Abortus (n=38) & Normal $(n=38)$ & & \\
\hline p53 Ser $46(\mathrm{U} / \mathrm{mL})$ & & & 4.413 & $<0.001^{* *}$ \\
\hline$\overline{\mathrm{X}}(\mathrm{SD})$ & $0.114(0.023)$ & $0.095(0.013)$ & & \\
\hline Median & 0.11 & 0.09 & & \\
\hline Range & $0.09-0.17$ & $0.08-0.14$ & & \\
\hline $\mathrm{Bcl}-2$ (ng/mL) & & & 1.928 & $0.027 *$ \\
\hline$\overline{\mathrm{X}}(\mathrm{SD})$ & $7.265(1.712)$ & $7.493(3.939)$ & & \\
\hline Median & 7.115 & 6.445 & & \\
\hline Range & $2.60-11.15$ & $5.58-29.44$ & & \\
\hline Caspase $3(\mathrm{mg} / \mathrm{mL})$ & & & 5.913 & $<0.001 * *$ \\
\hline$\overline{\mathrm{X}}(\mathrm{SD})$ & $112.74(152.73)$ & $14.94(23.18)$ & & \\
\hline Median & 76.5 & 12.62 & & \\
\hline Range & $6.50-707.75$ & $0-76$ & & \\
\hline
\end{tabular}

Explanation: $*=$ significant $(\mathrm{p} \leq 0.05), * *=$ very significant $(\mathrm{p} \leq 0.01)$

$\mathrm{Z}_{\mathrm{M}-\mathrm{W}}=$ Mann-Whitney test

Table: 3. Abortion Risks Based on Value Cut-off Levels of Protein p53 Ser 46, Bcl-2 and Caspase 3

\begin{tabular}{|c|c|c|c|c|}
\hline \multirow{2}{*}{ Variable } & \multicolumn{2}{|c|}{ Gestation } & \multirow{2}{*}{ P-values * } & \multirow{2}{*}{ OR $(95 \%$ CI $)$} \\
\hline & Abortus $(n=38)$ & Normal $(n=38)$ & & \\
\hline p53 Ser $46(\mathrm{U} / \mathrm{mL})$ & & & $<0.001$ & $8.52(2.65-28.6)$ \\
\hline$\overline{>} 0.09$ & $31(81.6 \%)$ & $13(34.2 \%)$ & & \\
\hline$\leq 0.09$ & $7(18.4 \%)$ & $25(65.8 \%)$ & & \\
\hline $\mathrm{Bcl}-2$ (ng/mL) & & & 0.008 & $3.75(1.24-11.68)$ \\
\hline$>6.44$ & $30(78.9 \%)$ & $19(50 \%)$ & & \\
\hline$\leq 6.44$ & $8(21.1 \%)$ & $19(50 \%)$ & & \\
\hline Caspase $3(\mathrm{mg} / \mathrm{mL})$ & & & $<0.001$ & $71.15(8.74-578.92)$ \\
\hline$>7$ & $37(97.4 \%)$ & $13(34.2 \%)$ & & \\
\hline$\leq 7$ & $1(2.6 \%)$ & $25(65.8 \%)$ & & \\
\hline
\end{tabular}


Explanation: * based on Chi-Square test

Table: 4. Logistic Regression Analysis of Multiple Protein p53 Ser 46, Bcl - 2 and Caspase 3 with Incident abortion

\begin{tabular}{|l|c|c|c|c|}
\hline Variable & Koef $\boldsymbol{\beta}$ & SE & p-Values & OR $_{\text {adj }}(\mathbf{9 5 \%}$ CI) \\
\hline $\begin{array}{l}\mathrm{p} 53 \text { Ser } 46(\mathrm{U} / \mathrm{mL}) \\
(>0.09 \mathrm{vs} \leq 0.09)\end{array}$ & 1.744 & 0.695 & 0.012 & $5.72(1.46-22.33)$ \\
\hline $\begin{array}{l}\text { Bcl-2 }(\mathrm{ng} / \mathrm{mL}) \\
(>6.44 \mathrm{vs} \leq 6.44)\end{array}$ & 1.227 & 0.711 & 0.084 & $3.41(1.06-11.02)^{*}$ \\
\hline $\begin{array}{l}\text { Caspase } 3(\mathrm{mg} / \mathrm{mL}) \\
(>7 \mathrm{vs} \leq 7)\end{array}$ & 3.963 & 1.11 & $<0.001$ & $52.60(5.97-463.15)$ \\
\hline Constanta & -4.855 & \multicolumn{4}{|l}{} \\
\hline
\end{tabular}

Explanation: The accuracy of the model $=88.2$

OR adj adjusted odds ratio $=$ value; $*$ ) Test of the parties

Table 5: Opportunities occurrence of abortion based Risk Factors Levels of Protein p53 Ser 46, Bcl-2 and Caspase 3

\begin{tabular}{|c|c|c|c|}
\hline p53 Ser $46(\mathrm{U} / \mathrm{mL})$ & Bcl-2 (ng/mL) & Caspase $3(\mathrm{mg} / \mathrm{mL})$ & Incident Abortion $\mathrm{P}(\mathrm{Y})^{\mathrm{x}}$ \\
\hline$\leq 0.09$ & $\leq 6.44$ & $\leq 7$ & 0.008 \\
\hline$\leq 0.09$ & $\leq 6.44$ & $>7$ & 0.291 \\
\hline$\leq 0,09$ & $>6.44$ & $\leq 7$ & 0.026 \\
\hline$\leq 0.09$ & $>6.44$ & $>7$ & 0.583 \\
\hline$>0.09$ & $\leq 6.44$ & $\leq 7$ & 0.043 \\
\hline$>0.09$ & $\leq 6.44$ & $>7$ & 0.701 \\
\hline$>0.09$ & $>6.44$ & $\leq 7$ & 0.132 \\
\hline$>0.09$ & $>6.44$ & $>7$ & 0.889 \\
\hline
\end{tabular}

Explanation: ${ }^{\mathrm{x}}$ calculated as logistic regression model

\section{Discussion}

The characteristics of the study subjects included were maternal age, parity, and gestational age because these characters act as a risk factor for abortion potentially confounding variables that could affect the validity of the study. Characteristics of study subjects Ser 46 levels of p53 protein, $\mathrm{Bcl}-2$ and caspase 3 compared between cases, ie an incomplete abortion and the control group, which is a normal pregnancy. To reduce the confusion, we used cases and controls with homogeneous characteristics. Abortion happens to gestational age less than 10 weeks allegedly influenced by immunological factors and chromosomes, whereas at 10 weeks gestation or more influenced by external factors, such as infections, malnutrition, trauma, or systemic disease ${ }^{[2,7,10]}$. In this study, only women with gestational age of 10 weeks or more are included so that it can be removed possibility immunological factors and chromosomes that can cause abortion.

It was generally agreed that the state of maternal age $\geq 35$ years and with the increasing number of parity would be associated with an increase in the number of abortus ${ }^{[7,20]}$. Therefore, in this study only mothers aged less than 35 years were included in the study, considering maternal age $\geq 35$ years found an increase in the number of abortions. Based on Table 2 showed levels of Bcl - 2 in the abortion group had a mean lower than in the normal group and differ very significantly $(p<0.01)$, whereas for protein levels of p53 Ser 46 and caspase 3 in the abortion group had a mean higher compared with the normal group different highly significant $(p<0.01)$. Savion et al reported a decrease in Bcl-2 associated with apoptosis and ends with abortion in animal experiments ${ }^{[18]}$. Bcl2 protein is an anti-apoptotic protein strong measure to 
prevent the cells from death and levels remain high in the outer mitochondrial membrane. Bcl-2 protein can also be used as an early detection apoptosis. Abortion in the first trimester of pregnancy is closely linked to an increase in apoptosis in syncytiotrophoblast compared to normal pregnancy. ${ }^{[22]}$ Unlike immunohistochemistry examination, in this study with ELISA examination the serum sample derived from an unknown where the apoptosis takes place. In this study, a decrease in the levels of Bcl-2 in abortion patients compared with normal pregnancy. It shows the mitochondrial pathway plays a role apoptosis in pregnancy failure induced by regulation of Bcl-2 [12, 17, 21, 22].

In this study, table 3, 4, and 5 showed increased levels of caspase 3 was very significant in abortion patients compared with normal pregnancy $(\mathrm{p}<0.001)$. This supports the theory that the higher the levels of caspase 3 in the first trimester of pregnancy will be more at risk of pregnancy failure. Involvement proapoptosis activators can cause excessive apoptosis, followed by cell death characterized by increased levels of caspase-3, and finally continue with abortion. Increased fetal resistance to stress teratogen is an outcomes of maternal immunopotentiating associated with a decrease in the intensity of apoptosis induced teratogenic substances on fetal structure targets. These findings indicate maternal immunopotentiating effect can be produced through the modification of the expression of molecular regulation of apoptosis induced teratogenic substances. P53 expression increase significantly in pregnancies with fetal growth retardation, but did not get a reduction in the expression of $\mathrm{Bcl}-2$ meaningful, The different results shown in this study despite the increased levels of p53 Ser 46 on abortion, the result the average levels of Bcl-2 in the study subjects who experienced abortion is lower compared with normal pregnancy were significantly

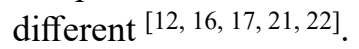

The protein p53 Ser 46, Bcl-2 and caspase 3 was significantly associated with the incidence of abortion. Multivariable sequence of the protein was strongly correlated with the incidence of abortion is caspase 3 , following the protein p53 Ser 46, and last Bcl-2. Caspase 3 has the strongest risk for abortion because caspase 3 serves as the main effectors in both basic apoptotic pathway, namely receptor-mediated pathway (extrinsic) and pathways mediated mitochondrial (intrinsic). Abnormal embryonic development involves several important things, namely: 1) apoptosis induced teratogenic substances can cause structural abnormalities; 2) the effect is obviously accompanied by increased expression of TNF- $\alpha$ and TNFR 1 in embryonic organ; 3) resistance/sensitivity of the various structures of the embryo to the substances teratogen depends on the interaction between positive regulators of apoptosis such as caspase 3,8 and $p 53$, while a negative regulator of apoptosis such as NF-kB and Bcl-2; 4) maternal immunopotentiating can affect the activity of molecules that cause apoptosis in the embryo as a response to adverse stimuli and modulate the sensitivity of embryos to teratogens substances. Similar results were obtained in our study, although not further investigated what factors are causing the failure of the pregnancy $[12,17,21,22]$.

Conflict of Interest: The authors reported no conflicts of interest.

Funding: This study is self-funding research.

Ethical Clearance: The study was approved by the Research Ethics Committee at the Faculty of Medicine Universitas Padjadjaran/Hasan Sadikin Hospital, Bandung, Indonesia

\section{References}

1. Kurjak A, Chervenak FA. Donald School Textbook of Ultrasound in Obstetrics and.

2. Gabbe SG, Niebyl JR, Simpson JL, Landon MB, Galan HL, Jauniaux ER, et al. Obstetrics: normal and problem pregnancies e-book: Elsevier Health Sciences; 2016.

3. Crum CP, Lee KR, Nucci MR, Granter SR, Howitt $\mathrm{BE}$, Parast MM, et al. Diagnostic Gynecologic and Obstetric Pathology E-Book: Elsevier Health Sciences; 2017.

4. Catt JW, Henman M. Toxic effects of oxygen on human embryo development. Human Reproduction. 2000;15(suppl_2):199-206.

5. Kurjak A, Chervenak FA, Carrera JM. The embryo as a patient: Parthenon Publishing; 2001.

6. Jauniaux E, Farquharson RG, Christiansen $\mathrm{OB}$, Exalto N. Evidence-based guidelines for the investigation and medical treatment of recurrent miscarriage. Human reproduction. 2006;21(9):2216-22.

7. Sara H, Garmel M. Early Pregnancy Risks; Current Obstetric and Gynecologic Diagnosis \& Treatment. McGraw-Hill Companies; 2003.

8. Lashen H, Fear K, Sturdee D. Obesity is associated 
with increased risk of first trimester and recurrent miscarriage: matched case-control study. Human reproduction. 2004;19(7):1644-6.

9. Speroff L, Fritz MA. Clinical gynecologic endocrinology and infertility: lippincott Williams \& wilkins; 2005.

10. Tomassetti C, Meuleman C, Pexsters A, Mihalyi A, Kyama C, Simsa P, et al. Endometriosis, recurrent miscarriage and implantation failure: is there an immunological link? Reproductive biomedicine online. 2006;13(1):58-64.

11. Pérez-Pérez A, Toro AR, Vilarino-Garcia $\mathrm{T}$, Guadix P, Maymó JL, Dueñas JL, et al. Leptin reduces apoptosis triggered by high temperature in human placental villous explants: The role of the p53 pathway. Placenta. 2016;42:106-13.

12. Liu G-P, Wei W, Zhou X, Zhang Y, Shi H-H, Yin $\mathrm{J}$, et al. I2PP2A regulates $\mathrm{p} 53$ and Akt correlatively and leads the neurons to abort apoptosis. Neurobiology of aging. 2012;33(2):254-64.

13. Leber B, Lin J, Andrews DW. Embedded together: the life and death consequences of interaction of the Bcl-2 family with membranes. Apoptosis. 2007;12(5):897-911.

14. Lea RG, Riley SC, Antipatis C, Hannah L, Ashworth CJ, Clark DA, et al. Cytokines and the regulation of apoptosis in reproductive tissues: a review. American Journal of Reproductive Immunology. 1999;42(2):100-9.

15. Brill A, Torchinsky A, Carp H, Toder V. The role of apoptosis in normal and abnormal embryonic development. Journal of assisted reproduction and genetics. 1999;16(10):512-9.
16. Torchinsky A, Toder V. To Die or Not to Die: the Function of the Transcription Factor NF- $\mathrm{kB}$ in Embryos Exposed to Stress. American Journal of Reproductive Immunology. 2004;51(2):138-43.

17. Toder V, Carp H, Fein A, Torchinsky A. The role of pro-and anti-apoptotic molecular interactions in embryonic maldevelopment. American journal of reproductive immunology. 2002;48(4):235-44.

18. Savion S, Lepsky E, Orenstein H, Carp H, Shepshelovich J, Torchinsky A, et al. Apoptosis in the uterus of mice with pregnancy loss. American Journal of Reproductive Immunology. 2002;47(2):118-27.

19. Jerzak M, Bischof P. Apoptosis in the first trimester human placenta: the role in maintaining immune privilege at the maternal-foetal interface and in the trophoblast remodelling. European Journal of Obstetrics \& Gynecology and Reproductive Biology. 2002;100(2):138-42.

20. Marchetti T, Cohen M, De Moerloose P. Obstetrical antiphospholipid syndrome: from the pathogenesis to the clinical and therapeutic implications. Clinical and Developmental Immunology. 2013;2013.

21. Reed JC. Bcl-2-family proteins and hematologic malignancies: history and future prospects. Blood, The Journal of the American Society of Hematology. 2008;111(7):3322-30.

22. Nurdianto AR, Suryokusumo MG. Elevation of Bcl2 Expression in Spiralis Artery of Pregnant Rattus norvegicus Infected with tachyzoite of Toxoplasma gondii with Hyperbaric Oxygen Therapy. Qanun Medika Jurnal Kedokteran FK UM Surabaya. 2019;3(2):157-67. 